\title{
Spiegelman Studies Part 2 of 2: Breakdowns, No Towers and the Rest of the Canon
}

\author{
Philip Smith* \\ Loughborough University
}

\begin{abstract}
Art Spiegelman is one of the most-discussed creators in Comic Book Studies. His Pulitzer-winning work Maus (1980 and 1991) was, alongside The Dark Knight Returns (1986) and Watchmen (1987), the catalyst to a sea change in the commercial and critical fortunes of the alternative comic book during the mid-1980s. It has been a landmark text in critical discourse on comics ever since. The purpose of this and its companion paper is to offer a synthesis and reinvestigation of both the existing critical literature on Spiegelman as well as, perhaps most importantly, the lacunae within that literature. The aims of these two papers, then, are two-fold: firstly, to establish where we have got to and, secondly, to suggest some directions for the future of Spiegelman scholarship. The first paper concerned Maus. This, the second of the two, is devoted to In The Shadow of No Towers (2004), Breakdowns (1977 and 2008), and Spiegelman's other works.
\end{abstract}

Spiegelman's Maus is, inarguably, one of the most important comics in the history of the medium and has accordingly, as we saw in Part 1 of this survey, attracted a great deal of critical attention. His subsequent works In the Shadow of No Towers (2004) and the reissue of his first collection Breakdowns (originally 1977, reissued in 2008) have generated considerable further interest. Breakdowns is Spiegelman's first collection of comics. It was made up of pieces created during the early- and mid-1970s and circulated in various underground comics including Funny Aminals (1972) and Short Order Comix (1973-1974). The first version of Breakdowns was collected in 1977. It was reissued in 2008 with the addition of Portrait of the Artist as a Young \%@\&*!, an introductory comic almost as long as the rest of the volume and which was, in part, autobiography. The comics of Breakdowns are characteristic of the underground genre of the 1960s and 1970s in that they are highly experimental, darkly humorous, anti-authoritarian, make heavy use of quotation and were circulated in small independent comics magazines. Within Breakdowns, Spiegelman shows a high degree of formal play with the comic book medium in terms of panel transitions, pacing and word-image combinations.

In the Shadow of No Towers was written in the aftermath of the September 11th 2001 terrorist attacks which Spiegelman witnessed at first-hand. They were originally created to be circulated episodically in the press, but in the political climate after the attacks, Spiegelman struggled to find a newspaper willing to carry the series in the United States and turned, instead, to European newspapers. In 2003, the American press began to publish images from the series. A hardback version, containing all 10 plates, an introductory essay and a series of early 20th century comics which Spiegelman selected for their charm and uncannily resonant foreshadowing of the attacks, was published in 2004. In the Shadow of No Towers contains multiple narrative sequences and artistic styles often within the same page. It is a chaotic and challenging reading experience, more similar to the experimental work found in Breakdowns than Maus. It also contains examples of biting political satire in the form of editorial cartoons, and numerous allusions to other comics. Many of those who knew Spiegelman entirely through Maus responded less than 
favourably to this comparatively experimental work; Wolk describes the text as a 'God-awful mess' which 'somehow became a book' (Wolk 2007, 346).

Breakdowns and In the Shadow of No Towers, along with Maus, are Spiegelman's three major comic book collections. These works, however, do not represent the entirety of the Spiegelman canon. Comix, Essays, Graphics, and Scraps (1999) and Co-Mix (2014) both contain his previously uncollected works. In addition to creating comics, Spiegelman was co-editor of the comic book magazines Arcade (1975 to 1976) and RAW (1980 to 1986 and 1987 to 1991), through which he helped to shape the growth of the medium. Spiegelman also lectured on comic books for more than 20 years first at the San Francisco Academy of Art and then at New York's School of Visual Arts. In his role as comic book celebrity and historian of the comic book form, he has written books, essays and anthology introductions and given talks on various subjects that range from Disney cartoonist Carl Barks, the translated version of Barefoot Gen Volume 2, the Tijuana Bibles and comic book creator Jack Cole.

Nor is Spiegelman's output limited exclusively to comics. His first job was as a cartoonist for Topps Gum from 1966 to 1989. He departed from the comic book form with an illustrated version of Joseph Moncure March's epic poem The Wild Party in 1994, and he co-created the musical and visual event Wordless with composer Phillip Johnston in 2014. Whilst his collections are generally, and Breakdowns specifically, intended for adults, Spiegelman's long career at Topps, his book Open Me ... I'm a Dog (1997) and his work as co-editor of Little Lit (2000-2003) make him as much a children's author as the creator of adult comics. He served as Contributing Editor/Staff Artist for the New Yorker from 1993 to 2003 where he produced many (in)famous covers including the black-on-black cover in the aftermath of September 11th 2001 and the controversial 1993 Valentine's day cover which showed a Hasidic Jew and an African woman locked in a kiss.

\section{In the Shadow of No Towers}

The central trends in criticism which concerns In the Shadow of No Towers, at least initially, concerned the relationship of the text to Maus. Subsequent criticism honed in on the relationship between Spiegelman and the protagonist of the text, the depiction of the traumatic moment, the process of resisting the act of mass-forgetting and the role of mediation through 'vision machines' (Paul Virilio's term from his 1994 book of the same name) within the text. The analysis below will provide an overview of this critical landscape whilst noting some potential problems and areas for development.

At the time of writing (circa 2015), there are 28 papers on In the Shadow of No Towers listed in the Bonner Online-Bibliographie Zur Comicsforchung database. This compares favourably with the majority of comic books, but this figure is still dwarfed by the 145 papers devoted to Maus. Whilst In the Shadow of No Towers has received some interest in its own right, many critics have read the collection as 'a sequel to Maus' or, at the very least, a text which sits squarely in the shadow of Spiegelman's tour de force. McGlothlin writes of being 'struck by how many critics devote a good deal of their discussion [of No Towers] to Maus' (McGlothlin 2008, 97). Scholars such as Kristiaan Versluys ('Art Spiegelman's In the Shadow of No Towers: 9-11 and the Representation of Trauma' 2006), Chute ('Temporality and Seriality in Spiegelman's In the Shadow of No Towers' 2007), Orbán (2007) and McGlothlin ('When Time Stands Still' 2008) herself have devoted part or all of their analysis to considering In the Shadow of No Towers as a thematic appendage to Maus.

This is perhaps unsurprising given that the publication of the collected edition of In the Shadow of No Towers took place in 2004, shortly after the publication of an essay collection on Maus, and coincided with a renaissance of critical interest in Spiegelman's work. Spiegelman also 
actively invites comparisons by including Maus-style mice in the text. As such, even those Spiegelman scholars such as Chute, who do not divide their attention between the two texts, still make extensive use of materials associated with the study of Maus (in Chute's case, for example, the question of 'temporal seepage'). Fewer critics, including Peter Sanderson ('Spiegelman's No Towers and Herriman's Krazy Kat' 2004), and Patrick M. Bray ('Aesthetics in the Shadow of No Towers: Reading Virilio in the Twenty-First Century' 2008), analyse the text purely in relation to its cultural and political contexts without recourse to criticism of Spiegelman's other work.

The fact that much of the critical discourse concerning In the Shadow of No Towers has been framed by Maus is not, of course, a reason to automatically dismiss this work to a position of secondary significance. All of the critics mentioned above highlight the dramatic difference in Spiegelman's artistic approach between the two texts. By reading the two in parallel, however, these critics forgo the possibility of stepping beyond the themes and artistic strategies which In the Shadow of No Towers shares with Maus.

In exploring the relationship between In the Shadow of No Towers and Maus, many critics have considered the problematic connections Spiegelman draws between the September 11th terrorist attacks and the Holocaust. Spiegelman makes this point explicit in his introduction to the collected volume: 'I remember my father trying to describe what the smoke in Auschwitz smelled like... The closest he got was telling me it was "indescribable"... That's exactly what the air in Lower Manhattan smelled like after Sept. 11' (Spiegelman 2004, 3). David Hajdu ('Homeland Insecurity' 2004) asserts that 'Spiegelman [Hajdu, like many critics, casually conflates Spiegelman with his protagonist] clearly sees Sept. 11 as his Holocaust (or the nearest thing his generation will have to personal experience with anything remotely correlative)' (Hajdu 2004, online). McGlothlin disagrees with the simplicity of Hajdu's statement but agrees that 'it is obvious that Spiegelman utilizes many of the skills and much of the knowledge he acquired in writing Maus for expressing his traumatized state after the terrorist attack' (McGlothlin 2008, 104). No one, Hajdu or Spiegelman included, would contend that the events of a single day, however tragic, are equivalent to the sustained industrial programme of segregation, torture, humiliation and eventually genocide enacted by the Nazis, but there nonetheless exists a symbolic language which connects the two. One such example is the recurring shoe imagery in the text. The 'other shoe' on plate 1 is a Doc Marten, a shoe which 'used to be more exclusively associated with aggressive urban male rebels and rightest groupings held together by ideologies of white supremacy' (Meyer 'Putting it into Boxes'; 2012, 484), evoking neo-Nazi and anti-Semitic iconography. This image also, of course, alludes to the 4000 shoes on display at the United States Holocaust Memorial Museum which has served as a metonym for the scale of the Nazi killing project.

Within In the Shadow of No Towers, Spiegelman's protagonist feels alienated because his own experience of the aftermath of the September 11th terrorist attacks differs dramatically from that of his peers. This has typically been read as a symptomatic signature of the trauma narrative. Examples of such readings include Versluys (2009), Martha Kuhlman ('The Traumatic Temporality of Art Spiegelman's In the Shadow of No Towers' 2007), Julie Reiser ('Thinking in Cartoons' 2014) and Alan Gibbs ('Against Collective Trauma: Art Spiegelman's In the Shadow of No Towers and Pluralistic Responses' 2012). Critical readings which focus on trauma typically view the text itself as the product of a disturbed mind and assume that the writing of In the Shadow of No Towers was essentially a therapeutic exercise for the creator. There is some disagreement as to how the transmission of Spiegelman's mental state works exactly within the text. Reiser, for example, argues that In the Shadow of No Towers does not represent the trauma-born failure of articulation. Rather, it represents a series of juxtapositions and a self-reflective focus upon form which facilitates direct communication of the author's mental state to the reader. Orbán (2007), 
conversely, contends that In the Shadow of No Towers articulates the impossibility of escape from the traumatic moment.

There is a tendency in all such criticism to read In the Shadow of No Towers as unproblematically autobiographical. Spiegelman's own trauma has shaped the work, and his sense of being uniquely traumatised within the text reflects, in part, the numerous rejections he experienced when trying to persuade American newspapers to publish In the Shadow of No Towers in its original format. Kuhlman, for example, submits that 'Spiegelman is forced to enter into a conversation with himself and the reader in order to create a dialogic space for his various reactions to $9 / 11$ ' (Kuhlman 2007, 853). In such a reading one might submit that Spiegelman seeks out a sympathetic listener to help mitigate his trauma. This approach is problematic, however, as it confuses the one who is written with the one who writes and thus denies the possibility of any degree of irony or critical distance between the author and character. Indeed, Spiegelman has been very clear that he, the author and Artie, the in-text author who appears in Maus, are not one and the same, and yet critics have tended to automatically splice his authorial persona in In the Shadow of No Towers with Spiegelman himself (see Spiegelman 2011, 34-35).

There have been several readings of In the Shadow of No Towers which offer an alternate focus beyond the preoccupation with the text's relationship to Maus and theories of trauma narrative. In Towering Figures: Reading the 9/11 Archive, Sven Cvek reads No Towers in relation to Walter Benjamin's philosophy of history: '[f] or both authors history is not underwritten by notions of progress or casual continuity, but defined by the eruption of the past into the present, following a pattern of cyclic repetition' (Cvek 2011, 95). Cvek's analysis echoes both the concept of 'temporal seepage' in Spiegelman's work and Brian Massumi's ('The Future Birth of the Affective Fact: The Political Ontology of Threat' 2010) contention that despite the apparent exceptionalism of the event, terrorist threats and attacks in fact have a long history. By alluding to the Shoah, figures from early American comics and the 1901 newspaper which lines the inside cover of In the Shadow of No Towers, Cvek argues that Spiegelman points to the 'deliberate forgetting of the past' in the narratives which saturated the media at the time (Cvek 2011, 96).

Bray reads the recurring image of the disintegrating North Tower through Virilio's concept of 'vision machines': technology which replaces the human experience of seeing (Bray (2008)). According to this reading, In the Shadow of No Towers freezes the moment of the "voluntary accident' (to use another term from the Virilio vocabulary) of the attacks and 'allows us to see causality within the image itself, the time and the accident inherent within the image, outside of an artificial historicising narrative' (Bray 2008, 16). Spiegelman's image of the North Tower dissolving is thus a semiotic, affective and political battleground between first-hand and technologically mediated experience. 'The fleeting memory of the moment just before the collapse of the North Tower, a memory threatened by the devastating force of media images, can only be represented by an image that exposes the danger of vision machines' (Bray 2008, 15).

In the Shadow of No Towers has emerged somewhat from the shadow of Maus. One hopes that in the future Spiegelman scholarship will increasingly regard the text in its own right rather than as a supplement. One productive avenue may be a comparative reading with another volume within the Spiegelman canon, one which, stylistically, In the Shadow of No Towers shares many stylistic characteristics, namely Breakdowns.

\section{Breakdowns}

Of Spiegelman's three major collections, Breakdouns has received the least critical attention. The limited amount of scholarship devoted to Breakdowns has gravitated towards the issues of hypertextuality, formal experimentation and defamiliarization. The only two texts in Breakdowns to have been the subject of significant scholarship are Prisoner on the Hell Planet and the original 
Maus. Prisoner on the Hell Planet, because it was reprinted in the later version of Maus, has typically been included in Maus criticism, most notably Hirsch's writing on postmemory. Some scholars, for example LaCapra (1998), have, in the course of their analysis, compared the original Maus, which was published in Funny Aminals (1972) and included in Breakdowns, to the Pulitzerwinning version serialised in $R A W$. The majority of the arguments concerning these two works are included in the sketch of Maus scholarship in the first half of this essay.

The 1977 version of Breakdowns had received relatively little critical attention, with James E. Young (At Memory's Edge 2000) and John Carlin (Masters of American Comics 2005) being noteworthy but somewhat brief exceptions. Until the reissue arguably the most in-depth analysis of Breakdowns was found in Spiegelman's own Comix, Essays, Graphics, and Scraps (see Spiegelman 1999), including an essay on the creation of his comic Don't Get Around Much Anymore in which he details the stylistic strategies at work. Spiegelman's own writing on the subject offered a practitioner-based approach which concentrated, as might be expected, on matters of artistic process. These essays have framed some of the critical readings which followed.

The work of Carlin and Bill Kartalopoulos ('Comics as Art: Spiegelman's Breakdowns' 2005) stands out in the field of criticism of Breakdowns. Both of these critics comment upon the 'hypertextuality' of the volume which includes, according to Kartalopoulos, stylistic allusions to Harvey Kurtzman's dark parodies in MAD magazine. Carlin offers further commentary on the stylistic makeup of the texts. He proposes that 'Spiegelman's strips were so densely impacted in terms of narrative and graphic design that they became more about themselves and their medium than the individual characters or situations they represented' (Carlin 2005, 128). Kartalopoulos, similarly, contends of Breakdowns that ' $[\mathrm{t}$ ] he whole work is undertaken as comics, without a desire to be anything but comics, and with a great faith that comics' traditional component elements retain the potential and plasticity to be reconfigured into a meaningful individual statement that satisfies the criteria of art' (Kartalopoulos; 2005, online). This is an important observation. Breakdowns is better read as a series of experiments with the comic book form, where structural elements are changed or removed in order to establish at what point the narrative ceases to function. It requires us to set aside, or at least relegate to a position of secondary significance, narrative content in its conventional sense and instead engage primarily with the question of form.

Kartalopoulos also analyses the subject of depression in Breakdowns. In this sense, the volume is typical of the Underground genre of the 1960s and 1970s in that its primary genre is semifictional autobiography. Whilst questions of self-writing are certainly relevant to Breakdowns, we must be wary, once more, of confusing Spiegelman's protagonist with the author. The ostentatious foregrounding of artifice in the texts serves as a constant reminder of the fact that these works are, at least in part, performed.

Further, noteworthy criticism of Breakdowns includes Bella Brodzki's contribution to Graphic Subjects: Critical Essays on Autobiography and Graphic Novels ('Breakdowns and Breakthroughs: Looking for Art in Young Spiegelman' 2011). Brodzki offers some key insights but her essay is short and focused almost exclusively on Portrait. Brodzki draws upon the seminal Russian Formalist essay, 'Art as Device', by Viktor Shklovsky (originally written in 1917, later published in Theory of Prose in 1925), which proposed that the function of art is to make everyday objects and the art object itself radically unfamiliar. In Breakdowns, Brodzki argues, Spiegelman defamiliarizes the artistic personae established in Maus. In the same volume, McGlothlin analyses the repeated 'squiggle' image which recurs throughout the opening comic. This squiggle, she contents 'viscerally expresses multiple and often contradictory ideas and emotions, such as concentration, contemplation, obsession, frustration, bewilderment, disorientation, creative insight, inspiration, mystery, ambiguity, incomprehensibility, and the opacity of meaning' (McGlothlin 2011, 47). 
Breakdowns is in many ways a paradigmatic text for formalist studies of comics in that it is stylistically rich, historically important and remains, largely, unchartered territory. Much could be made of the insertion of panels in Little Signs of Passion or the sequentially close sequence of images in Skinless Perkins. More work is needed in situating the volume within the evolution of the underground comics movement as a whole and in charting Spiegelman's fascinating experiments with the medium. Many subsequent works attest to the status of Breakdowns as a significant step in the evolution of the comic book in North America. One could trace a genealogy to connect pacing in the works of Chris Ware, and the multiple narrative paths found in Mark Carey's Unwritten directly back to the progenitive influence of Spiegelman's early work.

\section{Everything Else}

The remainder of Spiegelman's works, his illustrations for Topps, his covers for The New Yorker (both accepted and rejected), his illustrated version of The Wild Party, his book covers and his children's book Open Me... Im a Dog, have received, at most, casual asides within other works of Spiegelman scholarship. His lecture/slide-show/performance Wordless which he created with composer Johnston has been reviewed in the International Journal of Comics Art (Brian Cremins 'Wordless', 2014) and The Comics Journal, (Paul Tumey 'Art as Transformation: Wordless', 2014) and has been augmented by Hillary Chute's programme notes (Chute 'Introduction', 2014), but it has yet to be the subject of a full article. Co-Mix has, similarly, been reviewed (Paul Tumey 'Co-Mix' 2014) but not subject to in-depth analysis. Spiegelman's editorial work on $R A W$ has been the subject of two essays by Bill Kartalopoulos (2005a,b) and is discussed in the interviews collected by Joseph Witek (2007). In the same issue of Indy Magazine as his history of $R A W$, Kartalopoulos (2005) offers what is to date the only critical summary of Spiegelman's uncollected comics.

The reasons for this apparent absence of criticism beyond Spiegelman's major collections are two-fold. Firstly, Spiegelman is primarily known in the fields of Comics Studies, Literature and Oral Testimony. The Wild Party and Open Me... I $m$ a Dog are, to state the obvious, illustrated books. Wordless is perhaps best described as theatre, and the New Yorker covers and Topps illustrations are single images. As such, they require a critical vocabulary which exists outside of the major fields which typically engage with Spiegelman's works. Whilst there are obvious crossovers to the world of comics, these texts nonetheless present a potential disciplinary barrier to scholarship. Secondly, the majority of Spiegelman's non-comics works were either commissions or produced in collaboration and, as such, complicate the auteur approach which has dominated Spiegelman scholarship. In order to discuss a particular New Yorker cover, for example, one must first locate Spiegelman within the organisational and ideological structure of the magazine itself. This is unfortunate as many of Spiegelman's New Yorker covers, in particular, have offered powerful interventions in contemporary politics. One hopes that the publication of a collected volume of Spiegelman's work as an illustrator might become available at some point in the future and inspire a committed critical response.

\section{The Future of Spiegelman Scholarship}

As I write this paper, a book is being planned, edited by Drs Georgiana Banita and Lee Konstantinou, named The Comics of Art Spiegelman, which promises to both advance existing debates and fill many of the existing gaps in scholarship. Not only are comics scholars continuing to debate his works but also Spiegelman, himself, is still actively producing innovative and compelling works, and one hopes, therefore, that the future holds not only many more developments in Spiegelman scholarship but also many more works from the man himself. 
One promising area not mentioned so far is the use of Spiegelman's works in an educational context. Maus is taught all over the world from high schools onward, but Breakdowns, too, might be usefully employed in an undergraduate class on the comic book medium. His comic book scholarship, as both practitioner and historian, serve as excellent resources in teaching comics history. In this regard, Andrea Freud Lowenstein's 'Confronting Stereotypes: Maus in Crown Heights' (1998), Terry Barr's 'Teaching Maus to a Holocaust Class' (2009) and my own 'Maus in the Indonesian Classroom' (2014) may provide a starting point. One also hopes that in the future Spiegelman scholars may reach beyond Maus and In the Shadow of No Towers and comment in more detail the rest of the Spiegelman canon. The recent publication of Co-Mix has made Spiegelman's other works easily available. One also hopes that the works of Spiegelman's daughter Nadja Spiegelman, who, to date, has authored three works of comics for children, will receive critical attention both within the umbrella of Spiegelman criticism and in their own right.

\section{Short Biography}

Philip Smith obtained his PhD from Loughborough University in 2014. His work has been published in The Journal of Graphic Novels and Comics, Literature Compass, Journal of Southeast Asian Studies, International Journal of Comics Art, The Journal of European Studies, Asian Theatre Journal, Comics Forum, Slayage, and The Journal of Popular Culture. He blogs for The Hooded Utilitarian. He is co-editor of Firefly Revisited (Rowman and Littlefield) and the author of the forthcoming book Reading Art Spiegelman (Routledge). He teaches in Dubai.

\section{Note}

* Correspondence: Loughborough University, Loughborough, Leicestershire, UK. Email: philipsmithgraduate@gmail.com

\section{Works Cited}

Barr, Terry. 'Teaching Maus in the Holocaust Class.' Teaching the Graphic Novel. Eds. V. Hrsg and Stephen E. TabachnickOptions for Teaching, 27.. . New York: The Modern Language Assoc. of America, 2009. 76-83 Print .

Bray, Patrick M. 'Aesthetics in the Shadow of No Towers: Reading Virilio in the Twenty-First Century.' Yale Frenchv Studies 114 (2008): 4-17 Print.

Brodzki, Bella. 'Breakdowns and Breakthroughs: Looking for Art in Young Spiegelman.' Graphic Subjects: Critical Essays on Autobiography and Graphic Novels. Ed. Michael A. Chaney. Madison: University of Wisconsin Press, 2011. 51-58 Print.

Carlin, John. Masters of American Comics. New Haven: Yale University Press, 2005 Print.

Chute, Hillary. 'Temporality and Seriality in Spiegelman's "In the Shadow of No Towers"'. American Periodicals 17.2 (2007): 228-244. Print.

—. 'Introduction.' WORDLESS Program Notes. Chicago: University of Chicago, 2014 Print.

Cremins, Brian. 'WORDLESS! Art Spiegelman.' The International Journal of Comics Art Fall/Winter (2014): 674-677 Print.

Cvek, Sven. Towering Figures: Reading the 9/11 Archive. Amsterdam: Rodopi, 2011 Print.

Hajdu, David. 'Homeland Insecurity'. The New York Times 12 September 2004 [Online]. Accessed on 22 March 2013 from: http://query.nytimes.com.

LaCapra, D. History and Memory after Auschwitz. Ithaca: Cornell University Press, 1998 Print.

Massumi, Brian. 'The Future Birth of the Affective Fact: The Political Ontology of Threat.' The Affect Theory Reader. Eds. M. Gregg and G. J. Seigworth. . Durham: Duke University Press, 2010. 52-70 Print.

McGlothlin, Erin. 'Art Spiegelman and autobioGRAPHICal Re-vision.' Graphic Subjects: Critical Essays on Autobiography and Graphic Novels. Ed. M. A. Chaney. . Madison: University of Wisconsin Press, 2011. 45-50 Print.

—. 'When Time Stands Still.' The Jewish Graphic Novel. Eds. S. Baskind and R. Omer-Sherman. New Brunswick: Rutgers University Press, 2008. 94-110 Print.

Meyer, Christina. 'Putting it into boxes: Framing Art Spiegelman's In the Shadow of No Towers.' Amerikastudien / American Studies 55.3 (2012): 479-494 Print. 
Mouly, Françoise and Kartalopoulos, Bill. 'A RAW History Part One' Indy Magazine 23 December 2005a. Accessed on 23 March 2013

—. 'A RAW History Part Two' Indy Magazine 23 December 2005b. Accessed on 23 March 2013

Kartalopoulos, Bill. 'Comics as Art: Spiegelman's Breakdowns' Indy Magazine 23 December 2005. Accessed on 23 March 2013 from: www.indyworld.com/indy.

—. 'Borders, Breakdowns, and MAD-ness' Indy Magazine 23 December 2005. Accessed on 23 March 2013 from: www. indyworld.com/indy.

Kuhlman, Martha. 'The Traumatic Temporality of Art Spiegelman's In the Shadow of No Towers.' The Journal of Popular Culture 40:5 (2007): 849-866 Print.

Lowenstein, Andrea Freud. 'Confronting Stereotypes: Maus in Crown Heights.' College English 60.4 (1998): 396-420 p.400-401.

Orbán, Katalin. 'Trauma and Visuality: Art Spiegelman's Maus and In the Shadow of No Towers.' Representations 97 (2007): 57-89 Print.

Reiser, Julie. 'Thinking in Cartoons: Reclaiming Spiegelman's In the Shadow of No Towers.' Journal of Graphic Novels and Comics 5.1 (2014): 3-14 Print.

Sanderson, Peter. 'Spiegelman's No Towers and Herriman's Krazy Kat'. Comics in Context \#59: Before the Fall 22 October 2004. [Online]. Accessed on 23 March 2013 from: http://uk.ign.com/articles/2004/10/22/comics-in-context59-before-the-fall?page $=3$.

Shklovsky, Viktor. Theory of Prose. Champaign Il: Dakley Archive Press, 1991 Print.

Smith, Philip. 'Maus in the Indonesian Classroom'. Comics Forum. [Online]. 18 February 2014. Accessed on 12 August 2015 from http://comicsforum.org/2014/02/18/maus-in-the-indonesian-classroom-by-philip-smith/.

Spiegelman, Art. Open Me ... I'm a Dog. New York: HarperCollins, 1997 Print.

—. Comix, Essays, Graphics, and Scraps. Selerrio, Editore-La Centrale dell'Arte, 1999. Print.

- The Complete Maus. London: Penguin Books, 2003 Print.

- In the Shadow of No Towers. New York: Pantheon Books, 2004 Print.

—. 'Introduction.' Barefoot Gen: The Day After. Ed. K. Nakazawa. Vol. 2. San Fancisco: Last Gasp, 2005 Print.

- Breakdowns. New York: Pantheon, 2008 Print.

- Metamaus. New York: Pantheon, 2011 Print.

—. Co-Mix: Art Spiegelman. Montreal: Drawn Quarterly, 2013 Print.

Spiegelman, Art, and Françoise Mouly, eds. Read yourself RAW. New York: Pantheon, 1987 Print.

Z Zigg and Wikki: Something Ate MY Homework. New York: TOON Books, 2012 Print.

- Zigg and Wikki in 'The Cow'. New York: TOON Books, 2012 Print.

Spiegelman, Nadja and Sergio Garcia Sanchez. Lost in NYC: A Subway Adventure. New York: TOON Books, 2015 Print. Tumey, Paul. 'Art as Transformation: WORDLESS!' The Comics Journal. 17 December 2014. [Online]. Accessed on 4 April 2015 from: http://www.tcj.com/art-as-transformation-wordless/.

—. 'Co-Mix'. The Comics Journal 3 January 2014. [Online]. Accessed on 4 April 2015 from: http://www.tcj.com/reviews/co-mix-by-art-spiegelman/.

Versluys, Kristiaan. 'Art Spiegelman's In the Shadow of No Towers: 9-11 and the Representation of Trauma.' MFS Modern Fiction Studies 52.4 (2009): 980-1003.

- Out of the Blue. Bognor Regis: Columbia University, 2009 Print.

-Witek, Joseph ed. Art Spiegelman Conversations. Jackson: University Press of Mississippi, 2007 Print.

Wolk, Douglas. Reading Comics. Boston: Da Capo Press, 2007 Print.

Young, James E. At Memory's Edge: After-Images of the Holocaust in Contemporary Art and Architecture. New Haven: Yale University Press, 2000 Print. 